\begin{tabular}{c} 
Volume and Issues Obtainable at Center for Sustainability Research and Consultancy \\
Journal of Accounting and Finance in Emerging Economies \\
ISSN: 2519-0318 ISSN (E) 2518-8488 \\
Volume 6: Issue 2 June 2020 \\
CSRᄃ \\
Journal homepage: $\underline{\text { www.publishing.globalcsrc.org/jafee }}$ \\
\hline
\end{tabular}

\title{
CAPM Based Quantification of Bankruptcy Risk; A Heuristic Approach ${ }^{1}$ Areeba Khan, ${ }^{2}$ Sulaman Hafeez Siddiqui, ${ }^{3}$ Sohail Saeed, ${ }^{4}$ Muhammad Fahad Khan
}

${ }^{1}$ Department of Management Sciences, The Islamia University of Bahawalpur, Pakistan Email : areeba.khan@iub.edu.pk

${ }^{2}$ Department of Management Sciences, The Islamia University of Bahawalpur, Pakistan Email : sulman.siddiqui@iub.edu.pk

${ }^{3}$ Department of Commerce, The Islamia University of Bahawalpur, Pakistan Email : sohail.saeed@iub.edu.pk

${ }^{4}$ The Islamia University of Bahawalpur, Pakistan Email : fkhan_muhammad@yahoo.com

\begin{tabular}{ll}
\hline \multicolumn{1}{c}{ ARTICLE DETAILS } & ABSTRACT \\
\hline History & This paper builds on Capital Asset Pricing Model (CAPM) and its ability \\
Revised format: April 2020 & to validate market and firm specific risk. The effort is aimed at \\
Available Online: May 2020 & $\begin{array}{l}\text { ascertaining the role of bankruptcy risk in determining the cost of capital } \\
\text { in firms and its impact on corporate valuation. We also attempt to replace } \\
\text { and analyze disparity of systematic and unsystematic components of risk }\end{array}$ \\
\hline Keywords & with bankruptcy and risk of future liquidity. A similar study has \\
Capital; Liquidity risk, Firm & recently been carried out in Indian market by Shirur (2013) for \\
valuation & checking the validity of beta and cumulative risk measurement for \\
& identifying the presence of bankruptcy risk. This research may be \\
JEL Classification: & Pakistan. Therefore, the current study attempts to investigate the \\
& role of bankrupt0063y risk in determining the cost of capital in \\
& corporate valuation and the need of segregating systematic risk and \\
unsystematic risk into liquidity risk and bankruptcy risk. The & findings of this study suggest that unsystematic risk shall be eluded \\
while investing in a well-diversified portfolio, but after investing in & a specific firm, the unsystematic risk needs to be incorporated in \\
total corporate valuation.
\end{tabular}

Corresponding author's email address: areeba.khan@iub.edu.pk

Recommended citation: Khan, A., Siddiqui, S.H., Saeed, S., \& Khan, M.K. (2020). CAPM Based Quantification of Bankruptcy Risk: A Heuristic Approach. Journal of Accounting and Finance in Emerging Economies, 6 (2), 343-356

DOI: $10.26710 /$ jafee.v6i2.1155

\section{Introduction}

An investor faces a number of risks while investing in a company or a portfolio. The primary concern of investor is not only to know what return he is getting on his investment but the type and magnitude of the risk he will be facing on a certain investment. According to recent study by Shirur in 2013, the important risks which the investor faces are liquidity risk and bankruptcy risk and He, in the context of stock, further defined 'Liquidity risk' as the time taken by the stock to get back to its original price as it was at its 
purchase time and 'bankruptcy risk' as the condition where the prices of the stock declines at a level where there are not many chances of stock to regain its former value.

Capital Asset Pricing Model was proposed by Sharpe (1964) and Linter (1967) and was based on the work of Markowitz (1986) on diversification and Modern portfolio theory. Since then, a lot of work has been done on the development of this model by the researchers but it has also been under severe criticism. Chong, Jennings, \& Phillips (2018) state that the Capital Asset Pricing Model (CAPM) is used to calculate the required rate of return of asset that is being added in a diversified portfolio, for a known market risk/systematic risk which is represented by 'Beta' and it is determinant of the effect of risk related to individual stock on the risk of a diversified portfolio. CAPM is theoretically an ex ante model but, in terms of its application, it is generally done on ex-post data because its coefficient cannot be observed (Wiese, 2010)

Several studies have also highlighted the flaws for calculating beta and index which is used in the current methodology of CAPM. (Fritsch \& Franco, 1991; Choudhry, 2001; Javid \& Ahmad, 2011 ; Verma, 2011; Barai, 2015).

On the basis of the findings, which were applied on Indian market, Shirur (2013) has proposed that risk shall be classified into bankruptcy and risk of future liquidity instead of the classic systematic and unsystematic risk. This technique helps in the pricing of the unsystematic risk in total risk while determining the total cost of capital.

\subsection{Problem Statement}

As per the rationale and discussions above, the problem is that the Capital Asset Pricing Model only takes the systematic risk into account and ignores unsystematic risk. In case of investing in a well-diversified portfolio it can be ignored, but in context of a specific firm, the unsystematic risk gets relevant for investors as well as corporate finance managers so it needs to be incorporated in total risk valuation.

\subsection{Research Questions}

- Is the present method of measuring the total risk by using beta right?

- Is the corporate valuation significant if bankruptcy risk calculation is ignored?

\subsection{Research Objectives}

The objectives of this research are as follows:

- To investigate the validity of beta as per the current methodology of CAPM.

- To investigate the role of bankruptcy risk in determining the cost of capital in corporate valuation.

- To examine the possibility of replacing and analyzing systematic risk and unsystematic risk with liquidity risk and bankruptcy risk.

\subsection{Contribution to the existing literature/ Research gap}

The research has recently been carried out in Indian market by Shirur (2013) for checking the validity of beta and cumulative risk measurement for identifying the presence of bankruptcy risk. This research may be the first attempt at analyzing such semantics with data from Pakistan. Therefore, the current study attempts to investigate the role of bankruptcy risk in determining the cost of capital in corporate valuation and the need of segregating systematic risk and unsystematic risk into liquidity risk and bankruptcy risk.

\subsection{Significance of the study}

The results and findings of current study will guide the researchers and econometricians to develop such a model which could assimilate bankruptcy risk in corporate valuation. The other beneficiaries of this study 
would be policy makers, investors and corporate managers who want to measure the total risk associated with firms accurately.

\subsection{Hypothesis}

$\mathrm{H}_{\mathrm{o}}$ : Current methodology of CAPM to calculate beta is able to capture a consistent decrease in the stock prices.

$\mathrm{H}_{1}$ : Current methodology of CAPM to calculate beta is not able to capture a consistent decrease in the stock prices.

\section{Literature Review and Theory Formation}

There has been a lot of criticism on the assumptions of CAPM and researchers have raised questions on the basis of CAPM. Stieglitz (1967) provided contradictory evidence to one of the CAPM's assumptions that investors are always rational and risk averse and same set of information is available with the investors stating that investors intrinsically show unreasonable attributes by becoming risk takers when suffering losses but while earning profits they turn into risk averse. There has been a lot of work done on CAPM and some of the major developments were done by Lintner (1965) and Merton (1987) related to heterogeneous beliefs and by Black, (1972) related to removing the probability of risk-free borrowing and lending. Moreover, the other major extensions on CAPM were of Mayers (1973) and Breeden (1979) regarding non marketable assets, multiple time period and different investment opportunity for different time period.

Grossman \& Stiglitz (1980) conducted a study and found that it was costly for investors to be informed and hence can adjust risk and earn high returns as compared with an uninformed investor. The study of Stulz, 1981) and Adler \& Dumas (1983) extended the Capital asset pricing model by introducing the concept of International Investing. Ross (1989) states that the beta in Capital asset pricing model would be able to estimate the systematic risk only if the investment is properly diversified. Perold (2004) suggests that in order to diversify, the investors apportion their wealth among different risky portfolio, which contributes in the making of market portfolio as it is impossible to attain a single optimal portfolio of risky assets for every investor. The researcher further concluded that if CAPM is used to calculate cost of equity, several important decisions needs to made regarding the selection of market proxy, risk free rate, beta and time interval to calculate returns, which are based on logical judgment and experience of the practitioner (Wiese, 2010).

Duffie \& Lando (2001) developed a framework where risk on corporate debt increased due to incomplete information. In case of highly levered and distressed firms, their findings further revealed that in adverse economic conditions the market risk premium have an inverse relation with the risk associated with the firm. Zaretzky \& Kenton Zumwalt (2007) attempted to measure relative financial distress of firms and investigated that small size firms which are facing losses and are exposed to higher bankruptcy risk shows lower book to market values and earn lower returns with a consistent low risk premium

Sharp ratio and Treynor ratio has ignored bankruptcy risk and the only ratio which takes into account the bankruptcy risk is Sortino ratio developed by Sortino in 2010. Moreover, this ratio is an extension of Sharpe ratio and it includes only the standard deviation of negative assets return.

Liljeholm \& O'Doherty (2012) in their study conclude that the conditional CAPM capture the underperformance of stocks of distressed firms and stated that during bad economic conditions the distressed firms have low exposure to systematic risk. There have been several studies conducted to examine the stability of beta over the past twenty years. The study of Fama, French, Booth, \& Sinquefield (1993) has proposed that beta is unable to properly explain the change in expected returns. 
The study conducted by Das \& Barai (2016) provides evidence in literature which proves beta to be instable over time, stating that it can only be estimated as it is unobservable due to its dynamics. The study attempts to measure industry beta in Indian market and found that market risk of industry is sensitive to changes in global market. Hamid, Abdullah, Mustafa, Abidin, \& Ahmad (2015) conducted the study using monthly data of closing prices of $63 \mathrm{KSE}$ listed companies from a period of 2000 to 2012. The results of the study showed a negative relation between risk and return by using mean-variance CAPM whereas by using the downside risk based CAPM, the results showed a positive relation between risk and return (although statistically insignificant) which are consistent with the underlying theory.

\section{Conceptual Framework}

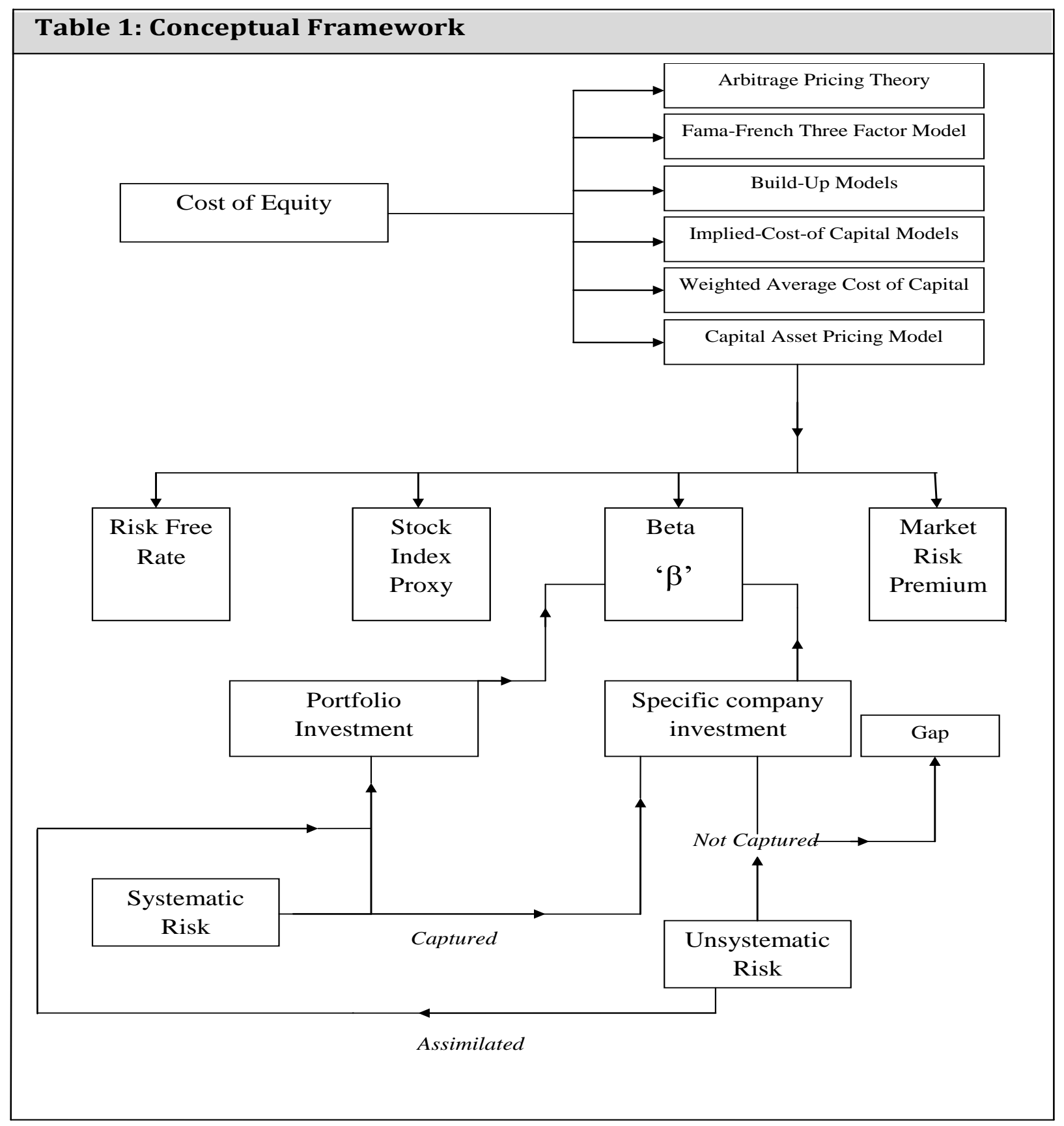

\section{Research Methodology}

\subsection{Sample and Procedures}

In order to examine and analyze the problem under study, secondary data of stock market consisting of 
daily closing prices of the KSE-100 index and ten KSE listed companies from $2^{\text {nd }}$ January 2006 to $3^{\text {rd }}$ January 2011, with over 1050 observations, have been used. These ten companies have been facing high risk but were not already bankrupt. This study uses the statistical and econometric techniques of Shirur (2013)

Unit root test has been applied to check whether the companies under study were facing risk or not. Cointegration test and Causality test were then applied on companies to find unit root in their series. The validity of beta used in current methodology of CAPM has also been analyzed by computing the average weekly and monthly beta of companies under study and the results are compared with the previous findings. CUSUM test has been applied to segregate risk and to find the degree of exposure to liquidity risk or bankruptcy risk separately.

\subsection{Unit Root Test:}

The mean and variance of a stationary series do not change systematically over time, whereas it is said to have a unit root if the time series is not stationary (Gujarati, 2006). Company which does not have a stable change in prices is facing both types of risks. If the series is not showing stationary trend then it states that series have increasing mean, standard deviation and variance and are facing risk. In order to check whether the series is stationary or non-stationary, this study used Augmented Dickey-fuller (ADF) tests (Dickey \& Fuller, 1979).

$$
\Delta Y_{t}=\alpha+\beta t+\gamma Y_{t-1}+\sum_{j=1}^{p}\left(\delta_{j} \Delta Y_{t-j}\right)+e_{t}
$$

( $t$ is the time index, $\alpha$ and $\beta$ are drift and the coefficient on a time trend, $\gamma$ is the coefficient presenting process root i.e. the focus of testing, $p$ is the lag order of the first-differences autoregressive process, ' $e_{t}$ ' is the error process with zero mean and constant variance.)

Companies which are not facing liquidity risk or bankruptcy risk do have a change in prices which is quite stable. The change in prices can be measured by drift and the time trend of equation having AR (1), and the series will show stationary trend as the value of coefficient $\gamma$ will be less than 1 . Whereas if the companies are facing high risk of liquidity and or bankruptcy risk, they will have a unit root in their first order auto-regression equation and coefficient value equal to 1. In ADF unit root test, the null hypothesis is accepted if the t-value of Yt-1 is less than the critical value and the series is said to be stationary while if the $\mathrm{t}$-value is larger than the critical value, it can be concluded that the series is non-stationary and have a unit root.

\subsection{Co-integration Test:}

The lack of cointegration of high bankruptcy risk companies in the index continuously diverges with the change in value. Whereas, Liquidity risk tends the stock prices of companies to converge to the variation in price of index because both the series are co-integrated. This study applies Johansen test famously developed by Johansen in 1991 to check if the stock prices of companies are co-integrated with index or not. If the series under study has a same unit root at first difference or second difference, the cointegration can be applied in order to check that if a group of some non-stationary time series data is cointegrated or not.

\subsection{Causality Test:}

This study makes use of Granger Causality Test (Granger, 1969) at $1^{\text {st }}$ lag to check whether the index causes share prices or not. If the Index Granger causes company's stock price then it shows that the company is facing liquidity risk. If the Index Granger does not cause stock price of a company then it can be said that the company may be exposed to significant bankruptcy risk. 


\subsection{Beta Stability:}

Beta used in the current methodology of Capital Asset Pricing Model does not assimilate the bankruptcy risk in it. This study will check and analyze the validity of beta by calculating the average weekly and monthly beta of the companies in the sample and will compare it with the results with previous findings.

\subsection{Cumulative Risk Measurement:}

This study uses the modified version of CUSUM test to divide total risk into bankruptcy and liquidity risk instead of systematic risk and unsystematic risk. In this test, stock prices were used to calculate risk rather than using return. The rationale for using stock prices was that bankruptcy risk is only analyzed with the trending of stock price and by using stock returns bankruptcy risk is completely ignored as lots of information is lost while calculating risk.

\section{Data Analysis}

KSE-100 is stock index which serves as a benchmark in order to compare stock prices on Karachi stock exchange over the time horizon of study. The index, with base of 1000 points, was launched in November 1991. The global crisis and other events which occurred after April 2008, led Karachi stock exchange to face severe downfall and the index dropped by more than one-third as it was in April 2008. Despite of such downfall, KSE index was able to quickly recover from those crises and reached new highs in 2009 and 2010. In order to examine the problem under study, ten companies have been selected which were facing either liquidity risk or bankruptcy risk after the market downfall in 2008. The companies understudy, along with their symbols, is shown in Table 2.

\begin{tabular}{|l|l|}
\hline Table 2: Companies and their Symbols \\
\hline Symbol & Name of the company \\
\hline IBFL & Ibrahim Fibre Limited \\
\hline ACPL & Attock Cement (Pakistan) Limited \\
\hline SEARL & The Searle Company Limited \\
\hline FFBL & Fauji Fertilizer Bin Qasim Limited \\
\hline$B W H L$ & Baluchistan wheels limited \\
\hline SMTM & Samin Textile Limited \\
\hline OLPL & Orix leasing \\
\hline$S B L$ & Samba bank \\
\hline NIB & NIB \\
\hline$T E L E$ & Telecard \\
\hline
\end{tabular}

\subsection{Companies and the Nature of Risk}

Searl Company Limited, Attock Cement Pakistan Limited, Ibrahim Fibre Limited and Fauji Fertilizer Bin Qasim Limited have been a part of KSE-100 index but were dropped from the index due to high fluctuation is prices after 2008. All these companies were financially strong as their nature of risk can be seen in the Table 3. The reversal in prices of these firms after crisis (mid-2008) can be seen where all these four companies were able to regain their former price and were able to move with the index which shows that these companies were facing liquidity risk. 


\begin{tabular}{|c|c|c|c|c|c|c|c|}
\hline \multicolumn{8}{|c|}{ Table 3: Significant Reversal of Prices } \\
\hline \multicolumn{2}{|c|}{ Searl Company Ltd } & \multicolumn{2}{|c|}{ Attock Cement } & \multicolumn{2}{|c|}{ Ibrahim Fibre Limited } & \multicolumn{2}{|c|}{$\begin{array}{c}\text { Fauji Fertilizer Bin Qasim } \\
\text { Limited }\end{array}$} \\
\hline Date & Price & Date & Price & Date & Price & Date & Price \\
\hline Jan 22006 & 42.4 & Jan 22006 & 85.05 & Jan 22006 & 38.8 & Jan 22006 & 25 \\
\hline Jul 32006 & 30 & Jul 32006 & 88.55 & Jul 32006 & 39.2 & Jul 32006 & 28.35 \\
\hline Oct 302007 & 44.85 & Jun 262007 & 125.75 & Mar 132008 & 71.1 & Jul 112007 & 42.75 \\
\hline Nov 232007 & 61.05 & May 82008 & 88.97 & Aug 272008 & 39.3 & Jul 162008 & 28.23 \\
\hline Dec 312007 & 45.45 & Sep 82008 & 44.40183 & Mar 42009 & 19.32 & Dec 242008 & 14.55 \\
\hline Jan 142008 & 62.3 & Jan 302009 & 31 & Sep 172009 & 37.42 & Jan 142010 & 28.95 \\
\hline Feb 72008 & 74.7 & Sep 292009 & 87.18 & Dec 312010 & 42.14 & Dec 282010 & 37.14 \\
\hline Mar 202008 & 61 & Dec 92009 & 46.8 & & & & \\
\hline Apr 92008 & 76.5 & Apr 232010 & 76.78 & & & & \\
\hline Apr 152008 & 92.9 & & & & & & \\
\hline Apr 222008 & 104.05 & & & & & & \\
\hline May 52008 & 89.4 & & & & & & \\
\hline May 122008 & 77.5 & & & & & & \\
\hline Jun 42008 & 90.09 & & & & & & \\
\hline Aug 12008 & 76.72 & & & & & & \\
\hline Jan 52009 & 61.66 & & & & & & \\
\hline Feb 262009 & 44.24 & & & & & & \\
\hline Apr 142009 & 60.5 & & & & & & \\
\hline Jun 222009 & 44.88 & & & & & & \\
\hline Sep 142009 & 63.09 & & & & & & \\
\hline Mar 42010 & 48.45 & & & & & & \\
\hline Jun 292010 & 59 & & & & & & \\
\hline Nov 32011 & 45.85 & & & & & & \\
\hline
\end{tabular}

Whereas Samin Textiles Limited, ORIX Leasing Pakistan Limited, Samba Bank, Baluchistan Wheels Limited, Telecard and NIB Bank which have been a part of KSE-100 index, were dropped from the index due to constant decrease in prices. This consistent decline in stock prices after the crisis in mid 2008 can be seen in Table 4. Companies were facing bankruptcy risk in addition with liquidity risk which made it hard for them to move with the index after such conditions. 


\begin{tabular}{|c|c|c|c|c|c|c|c|c|c|c|c|}
\hline \multicolumn{12}{|c|}{ Table 4: Significant Decline of Prices } \\
\hline \multicolumn{2}{|c|}{$\begin{array}{c}\text { Samin Textiles } \\
\text { Limited }\end{array}$} & \multicolumn{2}{|c|}{ Orix Leasing } & \multicolumn{2}{|c|}{ Samba Bank } & \multicolumn{2}{|c|}{$\begin{array}{c}\text { Baluchistan } \\
\text { Wheels Limited }\end{array}$} & \multicolumn{2}{|c|}{ Telecard } & \multicolumn{2}{|c|}{ NIB Bank } \\
\hline Date & Price & Date & Price & Date & Price & Date & Price & Date & Price & Date & Price \\
\hline Jan 22006 & 6.95 & Jan 22006 & 29.80 & Jan 22006 & 15.75 & Jan 22006 & 56.00 & Jan 22006 & 16.85 & Jan 22006 & 35.85 \\
\hline Jul 32006 & 16.25 & Jul 42006 & 25.50 & Mar 302007 & 18.00 & Dec 32007 & 84.00 & Jul 32006 & 10.85 & Jul 32006 & 19.50 \\
\hline Jul 252006 & 24.40 & Jan 122009 & 12.00 & Jul 112007 & 24.40 & Aug 202008 & 56.05 & Jul 52007 & 14.50 & Jul 152008 & 9.70 \\
\hline Oct 52006 & 32.00 & Jan 292009 & 6.40 & Jul 182008 & 9.94 & Mar 262009 & 28.80 & Nov 192007 & 10.05 & Jan 12009 & 4.89 \\
\hline Jun 132007 & 43.05 & & & May 72009 & 4.49 & & & Jul 222008 & 5.20 & Aug 302010 & 2.45 \\
\hline Sep 62007 & 49.29 & & & & & & & & & & \\
\hline May 222008 & 40.28 & & & & & & & & & & \\
\hline Jun 102008 & 32.00 & & & & & & & & & & \\
\hline Aug 52008 & 23.78 & & & & & & & & & & \\
\hline Aug 252008 & 16.38 & & & & & & & & & & \\
\hline Dec 302008 & 8.69 & & & & & & & & & & \\
\hline
\end{tabular}

\subsection{Criteria for Recording the Changes in Stock Prices:}

The fluctuation and the decline in prices of stocks have been recorded in Table 3 and Table 4. Since the period under study is from $2^{\text {nd }}$ January 2006 to $3^{\text {rd }}$ January 2011 , so each price reversal i.e. changes in price up to approximately 50 percent in either direction, has been recorded. The rationale to show such reversal in stock price was to examine the nature of risk these companies were facing.

\subsection{Unit Root Test of Share Prices}

As per Table 5, KSE-100 index and all the companies under study have been found to have ADF test statistics less than critical value at $90 \%$ confidence interval i.e. -2.5686 , which showed that series are nonstationary and has increasing mean and volatility over time. The finding suggested that the companies were either facing liquidity risk (if there is significant fluctuation in stock prices) or they were facing bankruptcy risk (if there is a constant decline in the stock prices). 


\begin{tabular}{|l|c|c|}
\hline \multicolumn{2}{|c|}{ Table 5: Unit Root Test of Share Prices } \\
\hline Value of Parameters & ADF test Statistic & Prob. \\
\hline kse-100 & -1.4511 & 0.5582 \\
\hline Ibrahim Fibre Limited & -1.7028 & 0.4296 \\
\hline Attock Cement (Pakistan) Limited & -1.7043 & 0.4288 \\
\hline The Searle Company Limited & -2.2315 & 0.1952 \\
\hline Fauji Fertilizer Bin Qasim Limited & -1.1800 & 0.6849 \\
\hline Baluchistan wheels limited & -0.8310 & 0.8093 \\
\hline Samin Textiles Limited & -0.9251 & 0.7806 \\
\hline Orix leasing & -1.1272 & 0.7070 \\
\hline Samba bank & -0.6656 & 0.8531 \\
\hline NIB & -1.2255 & 0.6654 \\
\hline Telecard & -1.3778 & 0.5945 \\
\hline Critical Values at $10 \%$ & -2.5686 & \\
\hline
\end{tabular}

\begin{tabular}{|l|c|c|}
\hline \multicolumn{3}{|c|}{ Table 6: Unit Root Test on First Difference of Share Prices } \\
\hline Value of Parameters & ADF test Statistic & Prob. \\
\hline kse-100 & -32.9078 & 0.0000 \\
\hline Ibrahim Fibre Limited & -36.3734 & 0.0000 \\
\hline Attock Cement (Pakistan) Limited & -35.4581 & 0.0000 \\
\hline The Searle Company Limited & -29.6004 & 0.0000 \\
\hline Fauji Fertilizer Bin Qasim Limited & -19.6111 & 0.0000 \\
\hline Baluchistan wheels limited & -28.6906 & 0.0000 \\
\hline Samin Textiles Limited & -32.3170 & 0.0000 \\
\hline Orix leasing & -38.2854 & 0.0000 \\
\hline Samba bank & -35.8893 & 0.0000 \\
\hline NIB & -19.0640 & 0.0000 \\
\hline Telecard & -30.7004 & 0.0000 \\
\hline Critical Values at 1\% & -3.4348 \\
\hline
\end{tabular}

\subsection{Unit Root Test on First Difference of Share Prices:}

As per Table 6, the ADF test statistic value of KSE-100 index and all the companies under study were higher than the critical values at $1 \%$ i.e. -3.4348 , which showed that series are stationary at first difference of share price. The findings also showed that the company's stock returns may come out to be stationary even if they are facing high variance and considerable amount of risk as the stock returns are relative first difference of stock price.

\subsection{Johansan Co-integration Test:}

In order to establish level of cointegration of companies' stock prices with KSE-100 index, 'Johansan Cointegration Test' was applied on all the companies under study. As per Table 7, the results provided evidence that the companies, which were expected to be facing liquidity risk during this time period, were co-integrated with the KSE-100 index. The trace statistics of Searl Company Limited, Attock Cement Pakistan Limited, Ibrahim Fibre Limited and Fauji Fertilizer Bin Qasim Limited is higher than the critical value at $5 \%$ level showing that the share prices of these companies do converge with the change in the KSE-100 index. 


\begin{tabular}{|l|c|c|c|c|}
\hline \multicolumn{5}{|c|}{ Table 7: Johansan Co-integration Test (January, 2006 to January, 2011) } \\
\hline \multicolumn{1}{|c|}{ Value of Parameters } & $\begin{array}{c}\text { Eigen } \\
\text { value }\end{array}$ & $\begin{array}{c}\text { Trace } \\
\text { Statistics }\end{array}$ & $\begin{array}{c}\text { Critical Value } \\
\text { at 5\% }\end{array}$ & Prob. \\
\hline Ibrahim Fibre Limited \& KSE-100 & 0.023673 & 28.84839 & 15.49471 & 0.0003 \\
\hline Attock Cement (Pakistan) Limited \& KSE-100 & 0.019221 & 23.12195 & 15.49471 & 0.0029 \\
\hline The Searle Company Limited \& KSE-100 & 0.013568 & 19.38504 & 15.49471 & 0.0123 \\
\hline Fauji Fertilizer Bin Qasim Limited \& KSE-100 & 0.01389 & 15.36402 & 13.42878 & 0.0423 \\
\hline Baluchistan wheels limited \& KSE-100 & 0.011497 & 10.51456 & 15.49471 & 0.2432 \\
\hline Samin Textiles Limited \& KSE-100 & 0.004483 & 5.654961 & 15.49471 & 0.7359 \\
\hline Orix leasing \& KSE-100 & 0.004585 & 5.670421 & 15.49471 & 0.7341 \\
\hline Samba bank \& KSE-100 & 0.002692 & 2.833804 & 15.49471 & 0.9739 \\
\hline NIB \& KSE-100 & 0.002713 & 3.603752 & 15.49471 & 0.9329 \\
\hline Telecard \& KSE-100 & 0.004656 & 6.065548 & 15.49471 & 0.6878 \\
\hline
\end{tabular}

\subsection{Validity of Beta:}

As exhibited in Table 9, the week on week mean beta of Fauji Fertilizer Bin Qasim Limited is 0.9732, for The Searle Company Limited it is 0.7564 and in case of Attock Cement (Pakistan) Limited it is 0.7529. Out of the entire sample understudy facing liquidity risk, only Ibrahim Fibre Limited showed a lower value for weekly average beta i.e. 0.4586 . It can also be seen that out of the six companies which were facing bankruptcy risk, only NIB bank (1.2619) and Telecard (1.6275) were able to show a relatively higher weekly average beta.

By comparing the weekly average beta of companies which were facing liquidity risk and bankruptcy risk, it can be seen that Searl Company Limited (0.7564), Attock Cement Pakistan Limited (0.7529) and Fauji Fertilizer Bin Qasim Limited (0.9732) have a higher beta values than Baluchistan Wheels Limited (0.4416) , Samin Textiles Limited (0.2325), ORIX Leasing Pakistan Limited (0.5190) and Samba Bank (0.4359), even though the prices of these companies have declined more than the companies which were facing liquidity risk. It can also be seen from Table 9 that the findings remained same even if companies' monthly average betas were compared instead of weekly average beta. So, according to the results and above comparison, it can be concluded that the standard beta only incorporates liquidity risk in it and ignores the risk of bankruptcy.

\begin{tabular}{|l|c|c|}
\hline \multicolumn{3}{|c|}{ Table 8: Degree of Stability of Beta (January, 2006 to January, 2011) } \\
\hline \multicolumn{1}{|c|}{ Companies Name } & Weekly Average Beta & Monthly Average Beta \\
\hline Ibrahim Fibre Limited & 0.4586 & 0.4173 \\
\hline Attock Cement (Pakistan) Limited & 0.7529 & 0.7208 \\
\hline The Searle Company Limited & 0.7564 & 0.6481 \\
\hline Fauji Fertilizer Bin Qasim Limited & 0.9732 & 0.9521 \\
\hline \multicolumn{3}{|c|}{} \\
\hline Baluchistan wheels limited & 0.4416 & 0.3085 \\
\hline Samin Textiles Limited & 0.2325 & 0.3119 \\
\hline Orix leasing & 0.5190 & 0.5938 \\
\hline Samba bank & 0.4359 & 0.4654 \\
\hline
\end{tabular}




\begin{tabular}{|l|c|c|}
\hline NIB & 1.2619 & 1.5120 \\
\hline Telecard & 1.6275 & 1.5743 \\
\hline
\end{tabular}

\subsection{Cumulative Risk Measurement:}

Cumulative risk measurement test, which is a modified version of CUSUM test, was applied and two periods were used to estimate both types of risks for the companies under study. First period is from $2^{\text {nd }}$ Jan' 2006 to $3^{\text {rd }}$ Jan' 2011, while the second period is from $2^{\text {nd }}$ Jan' 2006 to $1^{\text {st }}$ July' 2008. Volatility before the bearish drive as a result of negative shock was considered to be liquidity risk and change in volatility over the period of time after the bad news was considered as bankruptcy risk.

As per table 10, the companies facing only liquidity risk have fairly high standard deviation in both the periods but the volatility/mean, which is a measure of liquidity risk, has not changed much over the two periods, indicating that these companies are only facing liquidity risk. The change in volatility/mean over the two periods for Searl Company Limited is (4.9097-4.8542) 0.0555, in case of Attock Cement Pakistan Limited it is (7.2738-6.9761) 0.2977, for Ibrahim Fibre Limited it is (2.3461-2.0592) 0.2870 and for Fauji Fertilizer Bin Qasim Limited it is (2.2802-2.1531) 0.1271 which is negligible and it can be concluded that these companies are only facing liquidity risk.

\begin{tabular}{|c|c|c|c|c|c|c|c|}
\hline \multicolumn{8}{|c|}{ Table 9: Cumulative Risk Measurement } \\
\hline \multirow[b]{2}{*}{$\begin{array}{c}\text { Companies } \\
\text { Symbol }\end{array}$} & \multicolumn{3}{|c|}{ Jan 2006- Jan 2011} & \multicolumn{3}{|c|}{ Jan 2006- June 2008} & \multirow[b]{2}{*}{$\begin{array}{c}\text { Change In } \\
\text { Volatility/Mean }\end{array}$} \\
\hline & Mean & $\begin{array}{l}\text { Standard } \\
\text { Deviation }\end{array}$ & Volatility/Mean & Mean & $\begin{array}{l}\text { Standard } \\
\text { Deviation }\end{array}$ & Volatility/Mean & \\
\hline IBFL & 39.7324 & 9.6550 & 2.3461 & 45.3685 & 9.6655 & 2.0592 & 0.2870 \\
\hline ACPL & 77.2471 & 23.7040 & 7.2738 & 86.5390 & 24.5704 & 6.9761 & 0.2977 \\
\hline SEARL & 52.7931 & 16.0996 & 4.9097 & 37.4809 & 13.4885 & 4.8542 & 0.0555 \\
\hline FFBL & 30.1112 & 8.2860 & 2.2802 & 33.3912 & 8.4790 & 2.1531 & 0.1271 \\
\hline BWHL & 48.9222 & 20.7882 & 8.8334 & 67.6296 & 11.1891 & 1.8512 & 6.9822 \\
\hline SMTM & 18.1098 & 15.7643 & 13.7225 & 29.6053 & 15.2807 & 7.8871 & 5.8355 \\
\hline OLPL & 14.4138 & 10.0177 & 6.9624 & 27.7225 & 2.6559 & 0.2544 & 6.7079 \\
\hline SBL & 8.0042 & 7.3597 & 6.7672 & 17.3413 & 3.9027 & 0.8783 & 5.8889 \\
\hline NIB & 9.4207 & 8.4883 & 7.6482 & 21.7722 & 2.3002 & 0.2430 & 7.4052 \\
\hline TELE & 4.9811 & 3.9955 & 3.2049 & 10.7482 & 1.4185 & 0.1872 & 3.0177 \\
\hline
\end{tabular}

The lower half of the Table-10 shows initial variance and the change in variance of the companies facing bankruptcy risk, in addition to liquidity risk, over these two periods. This change in variance of all the firms facing bankruptcy risk was significantly high as compared with the change in variance of companies facing only liquidity risk. It can therefore be concluded that the results were in accordance with the previous findings and these six companies which are Samin Textiles Limited, ORIX Leasing Pakistan Limited, Samba Bank, Baluchistan Wheels Limited, Telecard and NIB Bank were facing bankruptcy risk after the market crisis in mid-2008.

\section{Findings}

After applying unit root test on all the firms under study, it was found that the series were non-stationary and were facing high risk. Out of those ten companies selected, Searl Company Limited, Attock Cement Pakistan Limited, Ibrahim Fibre Limited and Fauji Fertilizer Bin Qasim Limited were facing liquidity risk while Samin Textiles Limited, ORIX Leasing Pakistan Limited, Samba Bank, Baluchistan Wheels 
Limited, Telecard and NIB Bank were facing bankruptcy risk. The nature of risk, faced by these companies, can be seen in Table 3 and Table 4. Co-integration test and Granger Causality test were applied to check whether the results of these tests are consistent with the previous findings and it was found that companies, which were exposed to risk of liquidity, converge with the change in index whereas the companies, which were exposed to risk of bankruptcy, diverge with the change in index.

The research hypothesis of this study anticipates that beta in CAPM is not able to capture a consistent decrease in the stock prices. In order to check its righteousness, average weekly and monthly beta were estimated for companies facing both types of risks. Since the decline in prices is more for companies facing bankruptcy risk as compared to companies facing liquidity risk which suggest that their values of beta should also be greater. After calculating average weekly and monthly beta of these companies, the results showed that beta is unable to capture a consistent decline in stock prices. Thus, it can be concluded that the present method of beta estimation is not efficient in explaining the total risk and measuring cost of equity through CAPM is not significant enough if bankruptcy risk is ignored.

Moreover, instead of segregating risk into systematic and unique risk categories, a recent study by Shirur (2013) highlighted the need to segregate it into liquidity risk and bankruptcy risk. So, in order to explore such possibility, a modified version of CUSUM test (Brown, Durbin \& Evans, 1975) was applied on the ten companies understudy and an inter comparison was conducted between them. CUSUM test not only helps in identifying the nature of risk a company is facing, but also helps in finding the extent of that risk which companies face. The results of the test were consistent with the previous findings and the companies, which were facing bankruptcy risk, had a significant change in variance covariance matrix over both periods under study, while in case of companies facing liquidity risk had moderate change in coefficient of variance over the two periods.

\section{Conclusion}

The purpose of this study was to highlight the importance of capturing bankruptcy risk in cost-of-equity to make CAPM a more significant model in terms of its estimation. By using different statistical and econometric techniques mentioned in this study, the nature of risk can be identified and the extent of that risk can also be measured by using the modified version of CUSUM test in which risk is segregated into risk of future liquidity and bankruptcy risk. The advantage of using such technique is that it helps the unsystematic risk to get priced and the value of the firm can also be determined.

\section{References}

Adler, M., \& Dumas, B. (1983). International Portfolio Choice and Corporation Finance: A Synthesis. The Journal of Finance, Vol. 38, pp. 925-984. https://doi.org/10.1111/j.1540-6261.1983.tb02511.x

Ahmed, H., \& Javid, A. Y. (2009). The determinants of dividend policy in Pakistan. International Research Journal of Finance and Economics.

Altman, E. I. (1968). FINANCIAL RATIOS, DISCRIMINANT ANALYSIS AND THE PREDICTION OF CORPORATE BANKRUPTCY. The Journal of Finance. https://doi.org/10.1111/j.15406261.1968.tb00843.x

Barai, S. D. and P. (2015). Time-varying industry beta in Indian stock market and forecasting errors. (Unit 07), 1-5.

Black, F. (1972). capital market equilibrium with restricted borrowing.

Breeden, D. T. (1979). An intertemporal asset pricing model with stochastic consumption and investment opportunities. Journal of Financial Economics. https://doi.org/10.1016/0304-405X(79)90016-3

Chong, J., Jennings, W. P., \& Phillips, G. M. (2018). Finding The Beta For A Portfolio Isn't Obvious: An Educational Example. American Journal of Business Education (AJBE), 11(1), 15-22. https://doi.org/10.19030/ajbe.v11i1.10117

Choudhry, T. (2001). The long memory of time-varying beta: Examination of three emerging asian stock markets. Managerial Finance, 27(1-2), 5-23. https://doi.org/10.1108/03074350110767475

Das, S., \& Barai, P. (2016). Size, value and momentum in stock returns: evidence from India. 
Macroeconomics and Finance in Emerging Market Economies. https://doi.org/10.1080/17520843.2016.1148754

Davis, M. H. (2018). Empathy: A social psychological approach. In Empathy: A Social Psychological Approach. https://doi.org/10.4324/9780429493898

Dichev, I. D. (1998). Is the risk of bankruptcy a systematic risk? Journal of Finance, 53(3), 1131-1147. https://doi.org/10.1111/0022-1082.00046

Dickey, D. A., \& Fuller, W. A. (1979). Distribution of the Estimators for Autoregressive Time Series

With a Unit Root. Journal of the American Statistical Association. https://doi.org/10.2307/2286348

Duffie, D., \& Lando, D. (2001). Term structures of credit spreads with incomplete accounting information. Econometrica. https://doi.org/10.1111/1468-0262.00208

Durham, J., Jahns, R., \& Savage, D. (1954). Marine-nonmarine relationships in the Cenozoic section of California. California Division of Mines, Bulletin, 170, 59-71. Retrieved from http://scholar.google.com/scholar?hl=en\&btnG=Search\&q=intitle:Marinenonmarine+relationships+in+the+Cenozoic+section+of+California\#0

Fama, E. F., French, K. R., Booth, D. G., \& Sinquefield, R. (1993). Differences in the Risks and Returns of NYSE and NASD Stocks. Financial Analysts Journal. https://doi.org/10.2469/faj.v49.n1.37

Granger, C. W. J. (1969). Investigating Causal Relations by Econometric Models and Cross-spectral Methods. Econometrica. https://doi.org/10.2307/1912791

Grossman, S. J., \& Stiglitz, J. E. (1980). American Economic Association On the Impossibility of Informationally Efficient Markets. The American Economic Review, 70(3), 393-408.

Hamid, M. R. A., Abdullah, M., Mustafa, Z., Abidin, N. B. binti Z., \& Ahmad, H. (2015). Conceptual Framework of Innovation Excellence Model for Higher Education Institutions. Procedia - Social and Behavioral Sciences. https://doi.org/10.1016/j.sbspro.2015.01.977

Harry Markowitz. (1986). The Functions of the Executive. The Academy of Management Review, 11(2), 456. https://doi.org/10.2307/258476

He, J., \& Ng, L. K. (1994). Economic Forces, Fundamental Variables, and Equity Returns. The Journal of Business. https://doi.org/10.1086/296648

Javid, A. Y., \& Ahmad, E. (2011). Asset Pricing Behaviour with Dual-Beta in Case of Pakistani Stock Market. The Pakistan Development Review, 50(2), 95-118. https://doi.org/10.30541/v50i2pp.95-118

Johansen, S. (1991). Estimation and Hypothesis Testing of Cointegration Vectors in Gaussian Vector Autoregressive Models. Econometrica. https://doi.org/10.2307/2938278

Liljeholm, M., \& O’Doherty, J. P. (2012). contributions of the striatum to learning, motivation, and performance: An associative account. Trends in Cognitive Sciences.

https://doi.org/10.1016/j.tics.2012.07.007

Linter, J. (1967). Lintner69.pdf.

Mayers, D. (1973). Nonmarketable Assets and the Determination of Capital Asset Prices in the Absence of a Riskless Asset. The Journal of Business, 46(2), 258. https://doi.org/10.1086/295528

Merton, R. C. (1987). A Simple Model of Capital Market Equilibrium with Incomplete Information. The Journal of Finance, 42(3), 483-510. https://doi.org/10.1111/j.1540-6261.1987.tb04565.x

Neumann and Morgenstern. (1989). Retrospective on the utility theory of von Neumann and Morgenstern. Journal of Risk and Uncertainty, 2(2), 127-157. https://doi.org/10.1007/BF00056134

Ohlson, J. A. (1980). Financial Ratios and the Probabilistic Prediction of Bankruptcy. Journal of Accounting Research. https://doi.org/10.2307/2490395

Perold, A. F. (2004). A Relevância de Prêmios por Risco Soberano e Risco Cambial no Uso do CAPM para a Estimação do Custo de Capital das Empresas. Journal of Economic Perspectives. https://doi.org/10.1257/0895330042162340

Ross, S. A. (1989). Information and Volatility: The No-Arbitrage Martingale Approach to Timing and Resolution Irrelevancy. The Journal of Finance, 44(1), 1-17. https://doi.org/10.1111/j.15406261.1989.tb02401.x

Sharpe, W. F. (1964). Capital Asset Prices: a Theory of Market Equilibrium Under Conditions of Risk. 
The Journal of Finance, 19(3), 425-442. https://doi.org/10.1111/j.1540-6261.1964.tb02865.x Shirur, S. (2013). Are managers measuring the financial risk in the right manner? An exploratory study. Vikalpa, 38(2), 81-94. https://doi.org/10.1177/0256090920130205

Sortino, F. A. (2010). The Sortino Framework for Constructing Portfolios. In The Sortino Framework for Constructing Portfolios. https://doi.org/10.1016/C2009-0-20183-8

Stulz, R. M. (1981). On the Effects of Barriers to International Investment. The Journal of Finance, 36(4), 923-934. https://doi.org/10.1111/j.1540-6261.1981.tb04893.x

Verma, R. (2011). Testing forecasting power of the conditional relationship between beta and return. Journal of Risk Finance, 12(1), 69-77. https://doi.org/10.1108/15265941111100085

Wiese, W. B. A. J. (2010). Cost of Capital. (Ias 36), 129-154.

Zaretzky, K., \& Kenton Zumwalt, J. (2007). Relation between distress risk, book-to-market ratio and return premium. Managerial Finance. https://doi.org/10.1108/03074350710779232 